\title{
Vitamin D Deficiency in Elderly With Diabetes Mellitus Type 2: A Review
}

\author{
Ioannis Papaioannou ${ }^{1}$, Georgia Pantazidou ${ }^{2}$, Zinon Kokkalis ${ }^{3}$, Neoklis Georgopoulos ${ }^{4}$, Eleni Jelastopulu
} 5

1. Orthopedics, General Hospital of Patras, Patras, GRC 2. Otolaryngology - Head and Neck Surgery, General Hospital of Patras, Patras, GRC 3. Orthopedics, University of Patras, Patras, GRC 4. Endocrinology, Diabetes and Metabolism, University of Patras, Patras, GRC 5. Department of Public Health, University of Patras, Patras, GRC

Corresponding author: Ioannis Papaioannou, john.pane1984@gmail.com

\begin{abstract}
Diabetes mellitus type 2 (T2DM) is an emerging public health issue with high prevalence among older adults (>60 years old). Taking into consideration the great increase in the elderly population (approximately 7.5 billion worldwide), we can easily understand the impact of this chronic disease and its complications. On the other hand, vitamin D deficiency (VDD) is also a serious public health problem with significant impacts and multiple health effects. The correlation between DM and VDD has been suggested and established from many observational studies, reviews, and meta-analyses.
\end{abstract}

The literature in PubMed and Google Scholar was searched for relevant articles published up to October 2020. The keywords used were the following: vitamin D deficiency, elderly, and diabetes mellitus type 2. Among the 556 articles retrieved, 90 full texts were eligible and only 34 studies (12 retrospective studies, two prospective cohorts, three meta-analyses, seven cross-sectional studies, nine randomized control trials (RCTs), and one observational study) met the inclusion criteria for the review. The author's name, year of publication, country, type of study, and the number of patients were reported.

According to this review there is adequate evidence to support the correlation between VDD and T2DM in the elderly. The results from the RCTs are more conflicting and more studies are needed to confirm the impact of vitamin D deficiency (VD) supplementation on metabolic and lipid profile, oxidative stress, and the complications of T2DM in older patients. VDD is clearly related with severe retinopathy, diabetic peripheral neuropathy, and poor cognition performance, while there is consensus about the beneficial effect of VD on peripheral artery disease, foot ulceration prevention, and wound healing. On the other hand, there is controversy about the effect of VD supplementation on cardiovascular adverse events, endothelial function, and estimated glomerular filtration rate (eGFR). Finally, the association of VDD with fragility fractures and depression in the elderly with T2DM is currently insufficiently studied and remains controversial.

Review began 12/21/2020 Review ended 01/04/2021 Published 01/05/2021

๑) Copyright 2021

Papaioannou et al. This is an open access article distributed under the terms of the Creative Commons Attribution License CC-BY 4.0., which permits unrestricted use, distribution, and reproduction in any medium, provided the original author and source are credited.
Categories: Endocrinology/Diabetes/Metabolism, Orthopedics, Epidemiology/Public Health Keywords: elderly population, diabetes mellitus type 2, vitamin-d deficiency, vitamin d supplementation, diabetic complications

\section{Introduction And Background}

Diabetes mellitus type 2 (T2DM) is an emerging public health issue with high prevalence among older adults ( $>60$ years old). The main causes are increased life expectancy and lifestyle alterations [1]. It is estimated that 20\% of elderly worldwide suffer from T2DM, while a similar proportion has undiagnosed T2DM [1]. Taking into consideration the great increase in the elderly population (approximately 7.5 billion worldwide), we can easily understand the impact of this chronic disease and its complications [1]. On the other hand, vitamin D deficiency (VDD) constitutes a significant public health problem with great impact (1 billion people in 2008 worldwide) and multiple health effects (skeletal and extra-skeletal) [2]. VDD is related to many chronic diseases, such as cognition, depression, osteoporosis, cardiovascular disease, hypertension, diabetes, and cancer [3]. It is worth noting that age over 50 years is considered among risk factors for VDD [3]. Malabsorption, reduced renal function, skin decline, reduced time outdoors, and some medications (anticonvulsants) are the main factors, which predispose the elderly to VDD and its consequences [2]. The correlation between DM and VDD has been suggested from many observational studies, although the establishment of this knowledge has been done by a systematic review and meta-analysis by Pittas et al. in 2007 [4]. The main pathophysiologic mechanisms that correlate VDD with DM are dysregulation of pancreatic beta-cell function, impaired insulin sensitivity, and increased systemic inflammation [4]. In the last two decades there has been expanding evidence describing the implications of VDD in patients with T2DM, although until now no review or meta-analysis concerning the impact of VDD in the elderly with T2DM has been conducted. The aim of this study is to fill this gap in the current literature concerning this age group. 


\title{
Review
}

\section{Eligibility according to PICOS (Population, Intervention, Comparison, Outcomes and Study) criteria}

\author{
Type of Study
}

All articles in English language assessing the correlation of vitamin D deficiency (VDD) and diabetes mellitus type 2 (T2DM) in the elderly population (>60 years old), the implications of VDD in elderly with T2DM, and the current evidence of vitamin D supplementation effects in this specific age group up to October 2020 were eligible. Studies were eligible if they were longitudinal (prospective or retrospective studies, prospective cohort, case-control, cross-sectional, randomized control and meta-analysis), and if they reported any association (complications) of VDD in elderly with T2DM such as cardiovascular disease, nephropathy, retinopathy, peripheral artery disease, cognition, neuropathy, fragility fractures, depression, and quality of life. Furthermore, observational studies which correlate VDD with elderly with T2DM and randomized control studies, which describe the effects of vitamin D supplementation in this specific patient group were also eligible in this review. We complemented the search by manual scanning of reference lists of identified articles. The search was limited to studies conducted in humans.

\section{Exclusion Criteria}

Studies with subjects with mean age below 60 years old were excluded from this review. Case series, case reports, animal studies, and studies published in languages other than English were also excluded.

Type of Participants

Elderly (>60 years old) with T2DM and VDD. The research was up to October of 2020.

Type of Outcome Measures

We included studies if they measured at least one of the following: correlation of VDD with elderly patients with T2DM, effects of vitamin D supplementation in elderly with T2DM, complications of VDD in this patient group such as nephropathy, retinopathy, peripheral artery disease, cognition, neuropathy, fragility fractures, depression, quality of life, and cardiovascular diseases.

Information Sources and Search Methods

A systematic manual search was conducted in PubMed (including ahead of print and Epub) and the first 100 articles of Google Scholar databases published up to October of 2020. The keywords used were the following: vitamin D deficiency, elderly, and diabetes mellitus type 2. Among the 556 articles retrieved, 90 full texts were eligible, and only 34 studies (12 retrospective studies, two prospective cohorts, three meta-analyses, seven cross-sectional studies, nine randomized control trials, and one observational study) met the inclusion criteria for the review. The author's name, year of publication, country, type of study, and the number of patients were reported. Titles and abstracts were screened by the author and full texts retrieved for the manuscripts found relevant for the topic and excluded clearly irrelevant articles. Additional articles were searched and identified through hand searching of the bibliography. The retrieved full-text articles were assessed for eligibility for inclusion and data were extracted by the authors. Any disagreement in the selection of articles and data was solved by consensus.

The different phases of the literature search are illustrated in Figure 1. 


\section{Cureus}

556 records identified

through the pubmed research

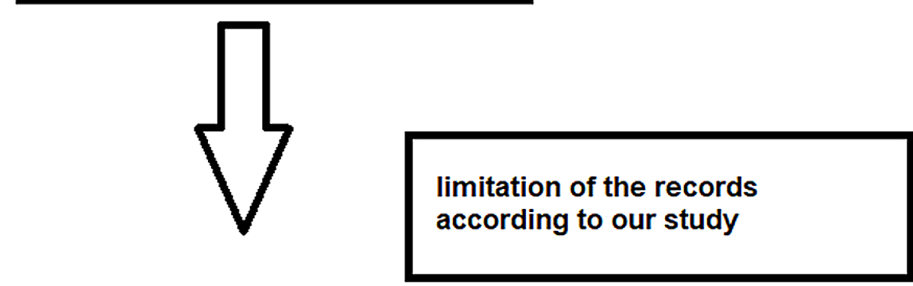

90 articles selected for

retrieval

exclussion of studies with mean

age $<60$ years old

59 articles met the above-

mentioned criteria

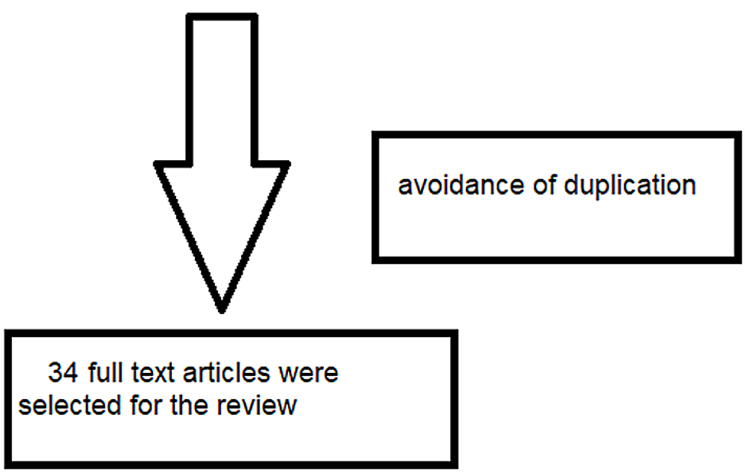

FIGURE 1: The different phases of the literature research.

For the assessment of study quality, the risk of bias assessment according to Newcastle-Ottawa was applied (Table 1). 


\section{Cureus}

\begin{tabular}{|c|c|c|c|}
\hline Author & Selection & Compatibility and outcome & Total score \\
\hline Wang et al [5] & 4 & 3 & 7 \\
\hline Lucato et al [6] & 4 & 3 & 7 \\
\hline Dalgard et al [7] & 4 & 3 & 7 \\
\hline Calvo-Romero et al [8] & 4 & 4 & 8 \\
\hline Kositsawat et al [9] & 4 & 4 & 8 \\
\hline Hurskainen et al [10] & 4 & 3 & 7 \\
\hline Zoppini et al [11] & 4 & 4 & 8 \\
\hline Lemieux et al [12] & 4 & 5 & 9 \\
\hline Wenclewska et al [13] & 4 & 5 & 9 \\
\hline Fagundes et al [14] & 4 & 3 & 7 \\
\hline Li et al [15] & 4 & 4 & 8 \\
\hline Kampmann et al [16] & 4 & 5 & 9 \\
\hline Witham et al [17] & 4 & 5 & 9 \\
\hline Herrmann et al [18] & 4 & 5 & 9 \\
\hline Samefors et al [19] & 4 & 3 & 7 \\
\hline Chen et al [20] & 4 & 3 & 7 \\
\hline Muscogiuri et al [21] & 4 & 4 & 8 \\
\hline Sugden et al [22] & 4 & 5 & 9 \\
\hline Angellotti et al [23] & 4 & 5 & 9 \\
\hline Yuan et al [24] & 4 & 3 & 7 \\
\hline Feldkamp et al [25] & 4 & 4 & 8 \\
\hline Razzaghi et al [26] & 4 & 5 & 9 \\
\hline Dall'Agnol et al [27] & 4 & 3 & 7 \\
\hline Peng et al [28] & 4 & 4 & 8 \\
\hline De Boer [29] & 4 & 5 & 9 \\
\hline Suzuki et al [30] & 4 & 3 & 7 \\
\hline Long et al [31] & 4 & 4 & 8 \\
\hline Zhang et al [32] & 4 & 5 & 9 \\
\hline Niu et al [33] & 4 & 4 & 8 \\
\hline Rui-hua et al [34] & 4 & 4 & 8 \\
\hline Westra et al [35] & 4 & 3 & 7 \\
\hline Alcubierre et al [36] & 4 & 4 & 8 \\
\hline Kim et al [37] & 4 & 3 & 7 \\
\hline Perez-Diaz et al [38] & 4 & 3 & 7 \\
\hline
\end{tabular}

TABLE 1: Quality of the selected studies by using the Newcastle-Ottawa scale.

Results 
A total of 556 studies were identified through the database search. Out of the 90 full texts retrieved, only 34 were included in the review (12 retrospective studies, two prospective cohorts, three meta-analyses, seven cross-sectional studies, nine randomized control trials, and one observational study), 14 were published in Europe, three in the USA, nine in China, two in Brazil and one each in Japan, Korea, Canada, Mexico, Iran, and Australia. A total of 62,381 patients were included in the review.

Most of the retrospective studies (10/12) revealed a high rate of VDD in elderly patients with T2DM and a strong correlation of VDD with many complications of T2DM in this patient group, such as diabetic foot ulceration, nephropathy, retinopathy, and cognition dysfunction. Although, a retrospective study conducted in 2016 didn't reveal a direct effect of VD on coronary heart disease and the last one published in 2015 didn't show any correlation between VD and hemoglobin A1c (HbA1c) or fragility fractures.

The results from the randomized control trials (RCTs) are conflicting, although most of them support that VD supplementation improves metabolic parameters (lipids, insulin resistance, glucose) and reduces also the complications of T2DM in elderly patients. In more detail, five out of nine RCTs recorded a positive impact of VD supplementation on metabolic profiles of the elderly with T2DM and also reduction of complications associated with T2DM such as improvement of endothelial function, wound healing in diabetic foot ulceration, reduction of microvascular and macrovascular disease events, improvement of blood pressure and b-type natriuretic peptide levels. On the other hand, two relatively small RCTs suggest that VD supplementation didn't improve metabolic profile, while the remaining two RCTs revealed no impact of VD in cardiovascular risk reduction and estimated glomerular filtration rate (eGFR) improvement.

The three meta-analyses included in this review concerning different aspects of this topic were all in agreement that VDD is associated with higher risk for T2DM development, VD supplementation reduces insulin resistance, and VDD is a risk factor for diabetic peripheral neuropathy.

Six out of seven cross-sectional studies concluded that VDD is correlated with many complications of T2DM in the elderly population. These complications are the following: myocardial dysfunction, peripheral artery disease, nephropathy, neuropathy, self-reported quality of life, and vertebral fracture risk. Only one crosssectional study didn't manage to settle VDD as a contributing factor of depression in elderly with T2DM.

Regarding the prospective studies, one of them supported that daily VD supplementation improves metabolic profiles and oxidative stress of elderly with T2DM, while the second study concludes that VDD is associated with increased risk of cardiovascular morbidity and mortality in these patients.

Finally, the unique observational study included in this review highlights that VDD is related with microvascular complications, insulin usage, and fragility fractures.

Table 2 summarizes the correlations and results between T2DM and VDD in the elderly population.

\begin{tabular}{|c|c|c|c|c|c|}
\hline Author & Year & Country & Study type & Patients & Results \\
\hline $\begin{array}{l}\text { Wang et al } \\
{[5]}\end{array}$ & 2018 & China & $\begin{array}{l}\text { Retrospective } \\
\text { study }\end{array}$ & 785 & High rate of VDD in patients with T2DM. PTH is a risk factor for FFs. \\
\hline $\begin{array}{l}\text { Lucato et al } \\
{[6]}\end{array}$ & 2017 & Italy & $\begin{array}{l}\text { Meta- } \\
\text { analysis }\end{array}$ & 28.258 & VDD is associated with higher risk for T2DM development. \\
\hline $\begin{array}{l}\text { Dalgard et } \\
\text { al [7] }\end{array}$ & 2011 & Faroe Islands & $\begin{array}{l}\text { Retrospective } \\
\text { study }\end{array}$ & 668 & VD sufficiency protects against T2DM development. \\
\hline $\begin{array}{l}\text { Calvo- } \\
\text { Romero et } \\
\text { al [8] }\end{array}$ & 2015 & Spain & $\begin{array}{l}\text { Retrospective } \\
\text { study }\end{array}$ & 103 & $\begin{array}{l}\text { VDD is associated with } 12 D M \text { and inverse correlations exISt } \\
\text { between VD status and metabolic control and insulin resistance. }\end{array}$ \\
\hline $\begin{array}{l}\text { Kositsawat } \\
\text { et al [9] }\end{array}$ & 2015 & USA & $\begin{array}{l}\text { Retrospective } \\
\text { study }\end{array}$ & 2.193 & VDD is associated with abnormal HbA1c. \\
\hline $\begin{array}{l}\text { Hurskainen } \\
\text { et al [10] }\end{array}$ & 2012 & Finland & $\begin{array}{l}\text { Retrospective } \\
\text { study }\end{array}$ & 1.756 & VDD is associated with impaired glucose and insulin metabolism. \\
\hline Zoppini et al & 2013 & Italy & $\begin{array}{l}\text { Retrospective } \\
\text { study }\end{array}$ & 715 & Inverse correlation of low VD and HbA1c. \\
\hline $\begin{array}{l}\text { Lemieux et } \\
\text { al [12] }\end{array}$ & 2019 & Canada & RCT & 96 & $\begin{array}{l}\text { VD supplementation for } 6 \text { months increases insulin sensitivity and b- } \\
\text { cell function in individuals with newly diagnosed T2DM. }\end{array}$ \\
\hline Wenclewska & 2019 & Poland & RCT & 92 & $\begin{array}{l}\text { Daily } 2000 \mathrm{IU} \text { intake of VD for three months reduced oxidative stress } \\
\text { and improved metabolic parameters (IR, glucose, lipids) in T2DM }\end{array}$ \\
\hline
\end{tabular}




\section{Cureus}

\begin{tabular}{|c|c|c|c|c|c|}
\hline et al [13] & & & & & patients. \\
\hline $\begin{array}{l}\text { Fagundes et } \\
\text { al [14] }\end{array}$ & 2019 & Brazil & $\begin{array}{l}\text { Prospective } \\
\text { study }\end{array}$ & 75 & $\begin{array}{l}\text { Daily } 4000 \text { lU intake of VD for } 8 \text { weeks improved glycemic, lipid and } \\
\text { hepatic profiles. Oxidative stress was also reduced in T2DM } \\
\text { patients. }\end{array}$ \\
\hline Li et al [15] & 2018 & China & $\begin{array}{l}\text { Meta- } \\
\text { analysis }\end{array}$ & 2.703 & VD supplementation reduces insulin resistance in T2DM patients. \\
\hline $\begin{array}{l}\text { Kampmann } \\
\text { et al [16] }\end{array}$ & 2014 & Denmark & RCT & 16 & $\begin{array}{l}\text { High dose of VD supplementation in T2DM patients didn't improve } \\
\text { the metabolic profile. }\end{array}$ \\
\hline $\begin{array}{l}\text { Witham et al } \\
{[17]}\end{array}$ & 2010 & $\begin{array}{l}\text { United } \\
\text { Kingdom }\end{array}$ & RCT & 61 & $\begin{array}{l}\text { High dose of VD supplementation in T2DM patients improved BP } \\
\text { and BNP levels, but not the IR, the HbA1c and endothelial function. }\end{array}$ \\
\hline $\begin{array}{l}\text { Herrmann et } \\
\text { al [18] }\end{array}$ & 2015 & $\begin{array}{l}\text { Australia } \\
\text { Finland New } \\
\text { zeland }\end{array}$ & RCT & 9.795 & $\begin{array}{l}\text { VDD is associated with microvascular and macro vascular disease } \\
\text { events in T2DM patients. }\end{array}$ \\
\hline $\begin{array}{l}\text { Samefors et } \\
\text { al [19] }\end{array}$ & 2017 & Sweden & $\begin{array}{l}\text { Prospective } \\
\text { study }\end{array}$ & 761 & $\begin{array}{l}\text { VDD is associated with increased risk of cardiovascular morbidity } \\
\text { and mortality in T2DM patients. }\end{array}$ \\
\hline $\begin{array}{l}\text { Chen et al } \\
\text { [20] }\end{array}$ & 2014 & China & $\begin{array}{l}\text { Cross } \\
\text { sectional } \\
\text { study }\end{array}$ & 95 & VDD is associated with myocardial dysfunction in T2DM patients. \\
\hline $\begin{array}{l}\text { Muscogiuri } \\
\text { et al }[21]\end{array}$ & 2016 & Italy & $\begin{array}{l}\text { Retrospective } \\
\text { study }\end{array}$ & 698 & $\begin{array}{l}\text { VD doesn't have a direct effect on CHD but may have an indirect } \\
\text { effect mediated by CVS risk factors such as diabetes duration, age, } \\
\text { and sex. }\end{array}$ \\
\hline $\begin{array}{l}\text { Sugden et al } \\
\text { [22] }\end{array}$ & 2008 & $\begin{array}{l}\text { United } \\
\text { Kingdom }\end{array}$ & RCT & 87 & $\begin{array}{l}\text { VD supplementation with one large dose improves endothelial } \\
\text { function in T2DM patients. }\end{array}$ \\
\hline $\begin{array}{l}\text { Angellotti et } \\
\text { al [23] }\end{array}$ & 2019 & USA & RCT & 127 & $\begin{array}{l}\text { VD supplementation with } 4000 \mathrm{IU} / \mathrm{day} \text { did not affect lipid profile and } \\
\text { CVD risk in patients with stable T2DM. }\end{array}$ \\
\hline $\begin{array}{l}\text { Yuan et al } \\
\text { [24] }\end{array}$ & 2019 & China & $\begin{array}{l}\text { Cross } \\
\text { sectional } \\
\text { study }\end{array}$ & 1.018 & VDD is associated with increased risk of PAD in T2DM patients. \\
\hline $\begin{array}{l}\text { Feldkamp et } \\
\text { al [25] }\end{array}$ & 2018 & Germany & $\begin{array}{l}\text { Retrospective } \\
\text { study }\end{array}$ & 104 & $\begin{array}{l}\text { VDD is associated with increased risk of diabetic foot ulcer } \\
\text { syndrome. }\end{array}$ \\
\hline $\begin{array}{l}\text { Razzaghi et } \\
\text { al [26] }\end{array}$ & 2017 & Iran & RCT & 60 & $\begin{array}{l}\text { VD supplementation for } 12 \text { weeks among patients with DFU } \\
\text { improved wound healing, oxidative stress, metabolic and lipid } \\
\text { profiles. . }\end{array}$ \\
\hline $\begin{array}{l}\text { Dall'Agnol et } \\
\text { al [27] }\end{array}$ & 2020 & Brazil & $\begin{array}{l}\text { Cross } \\
\text { sectional } \\
\text { study }\end{array}$ & 114 & VDD is associated with decreased GFR in patients with T2DM. \\
\hline $\begin{array}{l}\text { Peng et al } \\
\text { [28] }\end{array}$ & 2015 & China & $\begin{array}{l}\text { Retrospective } \\
\text { study }\end{array}$ & 448 & $\begin{array}{l}\text { Patients with T2DM with DN had lower VD levels. Status of VD can } \\
\text { be used to identify patients at increased risk of developing } \\
\text { nephropathy complications. }\end{array}$ \\
\hline De Boer [29] & 2011 & USA & RCT & 1.312 & $\begin{array}{l}\text { VD supplementation resulted in no significant difference in change in } \\
\text { e GFR at } 5 \text { years }\end{array}$ \\
\hline $\begin{array}{l}\text { Suzuki et al } \\
\text { [30] }\end{array}$ & 2006 & Japan & $\begin{array}{l}\text { Observational } \\
\text { study }\end{array}$ & 581 & $\begin{array}{l}\text { VDD is associated with microvascular complication and insulin } \\
\text { usage. VDD and insulin treatment is associated with FFs. }\end{array}$ \\
\hline $\begin{array}{l}\text { Long et al } \\
\text { [31] }\end{array}$ & 2017 & China & $\begin{array}{l}\text { Retrospective } \\
\text { study }\end{array}$ & 842 & VDD is associated with severe diabetic retinopathy \\
\hline $\begin{array}{l}\text { Zhang et al } \\
\text { [32] }\end{array}$ & 2019 & China & $\begin{array}{l}\text { Meta- } \\
\text { analysis }\end{array}$ & 2814 & $\begin{array}{l}\text { VDD is associated with DPN. VDD is a risk factor for DPN in T2DM } \\
\text { patients. }\end{array}$ \\
\hline Niu et al [33] & 2019 & China & $\begin{array}{l}\text { Cross } \\
\text { sectional } \\
\text { study }\end{array}$ & 1461 & $\begin{array}{l}\text { VDD is associated with DPN and might be used as a predictor of } \\
\text { DPN in elderly with T2DM. }\end{array}$ \\
\hline $\begin{array}{l}\text { Rui-hua et al } \\
\text { [34] }\end{array}$ & 2019 & China & $\begin{array}{l}\text { Retrospective } \\
\text { study }\end{array}$ & 173 & may predict poor cognitive performance in patients with T2DM. \\
\hline
\end{tabular}




\section{Cureus}

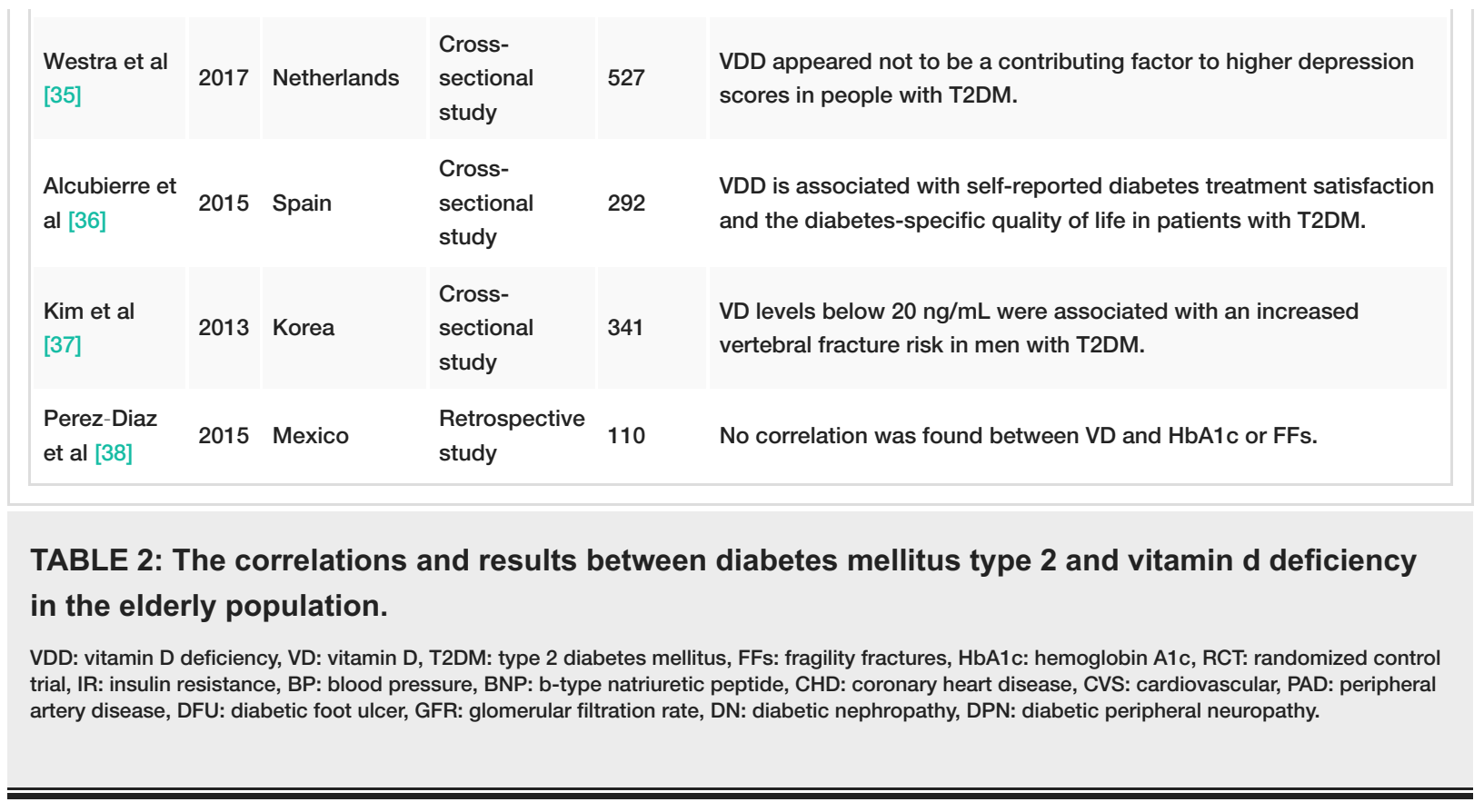

According to this review there is adequate evidence to support the correlation of VDD with T2DM in the elderly. The results from the RCTs are more conflicting and more studies are needed to confirm the impact of VD supplementation on metabolic and lipid profiles, oxidative stress, and the complications of T2DM in older patients. VDD is clearly related with severe retinopathy, diabetic peripheral neuropathy, and poor cognition performance, while there is consensus about the beneficial effect of VD on peripheral artery disease, foot ulceration, and wound healing. On the other hand, there is controversy about the effect of VD supplementation on cardiovascular adverse events, endothelial function, and eGFR improvement. Finally, the association of VDD with fragility fractures and depression in the elderly with T2DM remains controversial.

\section{Discussion}

Emerging evidence supports that VD is involved in glucose homeostasis and contributes to the pathophysiology of insulin resistance and diabetes mellitus. The exact pathophysiology is not clear yet, but the existing evidence suggests that VD improves beta-cell function (improvement of molecular repair mechanisms) and insulin sensitivity (reduction of oxidative damages, suppression of inflammatory response, and promotion of insulin signal transduction) [39].

All the epidemiological studies [5-11] (total seven studies; six retrospective and one meta-analysis) retrieved for this review correlate clearly VDD with T2DM in this age group (>60 years old). All these studies observed a high rate of VDD in patients with T2DM, while they also revealed inverse correlations between vitamin D status and metabolic control ( $\mathrm{HbA1c})$ and insulin resistance. It is worth noting that one of them supports that VD sufficiency protects against T2DM development.

The results from the studies in which different therapeutic regimens of vitamin D supplementation were administrated to examine the effects on metabolic control and insulin resistance were conflicting. Five studies (three randomized control studies, one meta-analysis, and one prospective study) [12-15,22] revealed that VD supplementation improved endothelial function, increased insulin sensitivity and b-cell function, reduced oxidative stress, and improved metabolic parameters to elderly with T2DM. On the other hand, two randomized control studies [16-17] with a small number of participants (in total 77 subjects) concluded that VD supplementation in this patient group didn't improve the metabolic profile (HbA1c or insulin resistance).

Among the remarkable findings is the role of VDD in the complications of T2DM in the elderly population. A large randomized control trial [18] (with 9,795 participants) confirmed that VDD is associated with microvascular and macrovascular disease events in elderly T2DM patients. Myocardial infarction and stroke constitute the macrovascular complications, while retinopathy, nephropathy, neuropathy, and peripheral artery disease are the main microvascular complications. As far as cardiovascular events are concerned, we found six relative studies. One prospective study [19] and one cross-sectional study [20] support that VDD is associated with increased risk of myocardial dysfunction, cardiovascular morbidity, and mortality in T2DM elderly patients. Although, a retrospective study [21] indicates that VD doesn't have a direct effect on coronary heart disease, but may have an indirect effect mediated by cardiovascular risk factors, such as diabetes duration, age, and sex. The three randomized control trials for this topic are also conflicting. The first in 2008 [22] supports that VD supplementation with one large dose improves endothelial function in 
T2DM patients, while the last in 2019 [23] concludes that VD supplementation with 4000 IU/day did not affect lipid profile and cardiovascular risk in patients with stable T2DM. In 2010 another RCT [17] revealed that a high dose of VD supplementation in T2DM patients improved blood pressure and b-type natriuretic peptide levels, but not the endothelial function. One observational study [30] showed that VDD is associated with microvascular complications and insulin usage in elderly with T2DM. The microvascular complications are the following: peripheral artery disease (PAD), nephropathy, and retinopathy. PAD is a devastating complication of diabetes mellitus with significant impact on the patient's functionality and health costs. We found three studies concerning VDD in elderly patients with PAD and T2DM: one cross-sectional study [24], one retrospective [25], and one RCT [26]. All of them support that VDD is associated with increased risk of PAD and diabetic foot ulcer formation, while the RCT concludes that VD supplementation for 12 weeks can improve wound healing. Regarding diabetic nephropathy, two studies (one cross-sectional and one retrospective study) [27-28] showed that VDD is associated with decreased glomerular filtration rate (GFR) and in addition VD status can be used to identify patients at increased risk of developing nephropathy complications. Although, an RCT [29] supports that VD supplementation resulted in no significant improvement of eGFR at five years. We retrieved only one study [31] for retinopathy for this patient group, which showed that VDD is clearly related with severe diabetic retinopathy. Diabetic peripheral neuropathy (DPN) can be a quite painful and disabling complication in elderly with T2DM. The two studies (one metaanalysis and one cross-sectional) [32-33] for DPN revealed that VDD is strongly correlated with DPN, while the VD status might be used as a predictor of DPN in elderly with T2DM. Cognition dysfunction is a relatively new complication of diabetes mellitus with partially undefined pathophysiology. We found only one retrospective study [34] published in 2019, which indicates that VDD may predict poor cognitive performance in patients with T2DM. VDD has been recently correlated with depression, although a crosssectional study [35] published in 2017 concerning elderly with T2DM concluded that VDD appeared not to be a contributing factor to higher depression scores in elderly with T2DM. Although, a cross-sectional study conducted in 2015 [36] showed that VD sufficiency is associated with higher self-reported diabetes treatment satisfaction and better diabetes-specific quality of life in elderly with T2DM. Fragility fractures (FFs) have a tremendous impact on elderly functionality, mental health, and physical activity. We identified four studies concerning FFs in elderly with T2DM and VDD. One cross-sectional study [37] revealed that VD levels below $20 \mathrm{ng} / \mathrm{ml}$ were associated with increased vertebral fracture risk in elderly men with T2DM. An observational study [30] showed that VDD and insulin treatment is associated with increased risk of FFs, while a retrospective study [5] concluded that elderly with T2DM and VDD accompanied with increased parathyroid hormone are associated with increased risk for FFs. On the other hand, a retrospective study published in 2015 [38] supports that there is no correlation between VDD and HbA1c or FFs in elderly with T2DM.

\section{Conclusions}

In the last 20 years there has been a tremendous increase in publications concerning vitamin D deficiency and diabetes mellitus type 2 , although elderly patients (>60 years old) didn't receive the required proportion of these studies. After the discussion of the results, we can easily understand that many issues of this topic are still unexplored.

Undoubtably, there is a definite correlation of VDD with T2DM in elderly patients. However, the effect of vitamin D supplementation on metabolic and lipid profile, oxidative stress, and the complications of T2DM in older patients require larger randomized controlled trials to confirm the thesis that vitamin D supplementation could be a possible intervention to improve insulin secretion and retard the progression of diabetes in type 2 diabetic subjects, reducing the upcoming complications. The definition of the exact threshold of vitamin D levels and the regimen of vitamin D supplementation is paramount of importance, although very difficult to be determined. Based on the small number of studies (excluding epidemiological studies and RCTs) of this patient group and the conflicting results in specific points of this topic, we strongly believe that there is an emerging need for new well-designed studies for the elderly population with T2DM and VDD.

\section{Additional Information \\ Disclosures}

Conflicts of interest: In compliance with the ICMJE uniform disclosure form, all authors declare the following: Payment/services info: All authors have declared that no financial support was received from any organization for the submitted work. Financial relationships: All authors have declared that they have no financial relationships at present or within the previous three years with any organizations that might have an interest in the submitted work. Other relationships: All authors have declared that there are no other relationships or activities that could appear to have influenced the submitted work.

\section{References}

1. Chentli F, Azzoug S, Mahgoun S: Diabetes mellitus in elderly . Indian J Endocrinol Metab. 2015, $19: 744$. 10.4103/2230-8210.167553

2. Chagas C, Borges MC, Martini LA, Rogero MM: Focus on vitamin D, inflammation and type 2 diabetes . Nutrients. 2012, 4:52-67. 10.3390/nu4010052 
3. Wang H, Chen W, Li D, Yin X, Zhang X, Olsen N, Zheng SG: Vitamin D and chronic diseases. Aging Dis. 2017, 8:346. 10.14336/AD.2016.1021

4. Pittas AG, Lau J, Hu FB, Dawson-Hughes B: The role of vitamin D and calcium in type 2 diabetes. A systematic review and meta-analysis. J Clin Endocrinol Metab. 2007, 92:2017-2029. 10.1210/jc.2007-0298

5. Wang XF, Yu JJ, Wang XJ, et al.: The associations between hypovitaminosis D, higher PTH levels with bone mineral densities, and risk of the 10-year probability of major osteoporotic fractures in Chinese patients with T2DM. Endocr Pract. 2018, 24:334-341. 10.4158/EP-2017-0164

6. Lucato P, Solmi M, Maggi S, et al.: Low vitamin D levels increase the risk of type 2 diabetes in older adults: a systematic review and meta-analysis. Maturitas. 2017, 100:8-15. 10.1016/j.maturitas.2017.02.016

7. Dalgard C, Petersen M, Weihe P, Grandjean P: Vitamin D status in relation to glucose metabolism and type 2 diabetes in septuagenarians. Diabetes Care. 2011, 34:1284-1288. 10.2337/dc10-2084

8. Romero JM, Lozano JM: Vitamin D levels in patients with type 2 diabetes mellitus . J Investig Med. 2015, 1. 10.1097/JIM.0000000000000234

9. Kositsawat J, Kuchel G, Tooze J, et al.: Vitamin D insufficiency and abnormal hemoglobin a1c in black and white older persons. J Gerontol A. 2015, 70:525-531. 10.1093/gerona/glu122

10. Hurskainen A, Virtanen J, Tuomainen T, Nurmi T, Voutilainen S: Association of serum 25-hydroxyvitamin D with type 2 diabetes and markers of insulin resistance in a general older population in Finland. Diabetes Metab Res Rev. 2012, 28:418-423. 10.1002/dmrr.2286

11. Zoppini G, Galletti A, Targher G, et al.: Glycated haemoglobin is inversely related to serum vitamin D levels in type 2 diabetic patients,. PLoS One. 2013, 8:e82733. 10.1371/journal.pone.0082733

12. Lemieux P, Weisnagel J, Caron A, et al.: Effects of 6-month vitamin D supplementation on insulin sensitivity and secretion: a randomised, placebo-controlled trial. Eur J Endocrinol. 2019, 181:287-299. 10.1530/EJE-190156

13. Wenclewska S, Pajor I, Drzewoski J, Bunk M, Śliwińska A: Vitamin D supplementation reduces both oxidative DNA damage and insulin resistance in the elderly with metabolic disorders. Int J Mol Sci. 2019, 20:2891. 10.3390/ijms20122891

14. Fagundes GE, Macan T, Rohr P, et al.: Vitamin D3 as adjuvant in the treatment of type 2 diabetes mellitus: modulation of genomic and biochemical instability. Mutagenesis. 2019, 34:135-145. 10.1093/mutage/gez001

15. Li X, Liu Y, Zheng Y, Wang P: The effect of vitamin D supplementation on glycemic control in type 2 diabetes patients: a systematic review and meta-analysis. Nutrients. 2018, 10:375. 10.3390/nu10030375

16. Kampmann U, Mosekilde L, Juhl C, et al.: Effects of 12 weeks high dose vitamin D3 treatment on insulin sensitivity, beta cell function, and metabolic markers in patients with type 2 diabetes and vitamin D insufficiency - a double-blind, randomized, placebo-controlled trial. Metabolism. 2014, 63:1115-1124. 10.1016/j.metabol.2014.06.008

17. Witham MD, Dove FJ, Dryburgh MO, Sugden JA, Morris AD, Struthers AD: The effect of different doses of vitamin D3 on markers of vascular health in patients with type 2 diabetes: a randomised controlled trial. Diabetologia. 2010, 53:2112-2119. 10.1007/s00125-010-1838-1

18. Herrmann M, Sullivan D, Veillard A, et al.: Serum 25-hydroxyvitamin D: a predictor of macrovascular and microvascular complications in patients with type 2 diabetes. Diabetes Care. 2015, 38:521-528. 10.2337/dc14-0180

19. Samefors M, Scragg R, Länne T, Nyström FH, Östgren CJ: Association between serum 25(OH)D 3 and cardiovascular morbidity and mortality in people with Type 2 diabetes: a community-based cohort study. Diabet Med. 2017, 34:372-379. 10.1111/dme.13290

20. Chen Y, Zhao CT, Zhen Z, Wong A, Tse HF, Yiu KH: Association of myocardial dysfunction with vitamin D deficiency in patients with type 2 diabetes mellitus. J Diabetes Complications. 2014, 28:286-290. 10.1016/j.jdiacomp.2014.01.003

21. Muscogiuri G, Nuzzo V, Gatti A, et al.: Hypovitaminosis D: a novel risk factor for coronary heart disease in type 2 diabetes?. Endocrine. 2016, 51:268-273. 10.1007/s12020-015-0609-7

22. Sugden JA, Davies JI, Witham MD, Morris AD, Struthers AD: Vitamin D improves endothelial function in patients with Type 2 diabetes mellitus and low vitamin D levels. Diabet Med. 2008, 3:320-325. 10.1111/j.1464-5491.2007.02360.x

23. Angellotti E, David D'Alessio D, Hughes B, et al.: Effect of vitamin D supplementation on cardiovascular risk in type 2 diabetes. Clin Nutr. 2019, 38:2449-2453. 10.1016/j.clnu.2018.10.003

24. Yuan J, Jia P, Hua L, Xin Z, Yang J-K: Vitamin D deficiency is associated with risk of developing peripheral arterial disease in type 2 diabetic patients. BMC Cardiovasc Disord. 2019, 19:145. 10.1186/s12872-019-11250

25. Feldkamp J, Jungheim K, Schott M, Jacobs B, Roden M: Severe vitamin D3 deficiency in the majority of patients with diabetic foot ulcers. Horm Metab Res. 2018, 50:615-619. 10.1055/a-0648-8178

26. Razzaghi R, Pourbagheri H, Heravi M, Bahmani F, Shadi J, Soleimani Z, Asemi Z: The effects of vitamin D supplementation on wound healing and metabolic status in patients with diabetic foot ulcer: a randomized, double-blind, placebo-controlled trial. J Diabetes Complications. 2017, 31:766-772. 10.1016/j.jdiacomp.2016.06.017

27. Dall'Agnol A, de Almeida Brondani L, da Agostim Cancelier V, Camargo EG, Silveiro SP: Lower serum 25hydroxyvitamin D levels are associated with impaired glomerular filtration rate in type 2 diabetes patients. Ther Adv Endocrinol Metab. 2020, 11:2042018820930904. 10.1177/2042018820930904

28. Peng Y, Li LJ: Serum 25-hydroxyvitamin D level and diabetic nephropathy in patients with type 2 diabetes mellitus. Int Urol Nephrol. 2015, 47:983-989. 10.1007/s11255-015-0983-3

29. de Boer IH, Katz R, Chonchol M, et al.: Serum 25-hydroxyvitamin D and change in estimated glomerular filtration rate. Clin J Am Soc Nephrol. 2011, 6:2141-2149. 10.2215/CJN.02640311

30. Suzuki A, Kotake M, Ono Y, et al.: Hypovitaminosis D in type 2 diabetes mellitus: association with microvascular complications and type of treatment. Endocr J. 2006, 53:503-510. 10.1507/endocrj.K06-001

31. Long M, Wang C, Liu D: Glycated hemoglobin A1C and vitamin D and their association with diabetic retinopathy severity. Nutr Diabetes. 2017, 7:e281-e281. 10.1038/nutd.2017.30

32. Zhang B, Zhao W, Tu J, et al.: The relationship between serum 25 -hydroxyvitamin D concentration and type 


\section{Cureus}

2 diabetic peripheral neuropathy: a systematic review and a meta-analysis. Medicine (Baltimore). 2019, 98:e18118. 10.1097/MD.0000000000018118

33. Niu Y, Li J, Peng R, Zhao X, Wu J, Tang Q: Low vitamin D is associated with diabetes peripheral neuropathy in older but not in young and middle-aged patients. Diabetes Metab Res Rev. 2019, 35: 10.1002/dmrr.3162

34. Rui-hua C, Yong-de P, Xiao-zhen J, Chen J, Bin Z: Decreased levels of serum IGF-1 and vitamin D are associated with cognitive impairment in patients with type 2 diabetes. Am J Alzheimer's Dis Other Dementias. 2019, 34:450-456. 10.1177/1533317519860334

35. Westra S, Simsek S, Rutters F, Krul-Poel YM, Stehouwer CD, Dekker JM, Pouwer F: Low vitamin D levels are not a contributing factor to higher prevalence of depressive symptoms in people with Type 2 diabetes mellitus: the Hoorn study. Diabet Med. 2017, 34:577-581. 10.1111/dme.13265

36. Alcubierre N, Valls J, Rubinat E, et al.: Vitamin D deficiency is associated with the presence and severity of diabetic retinopathy in type 2 diabetes mellitus. J Diabetes Res. 2015, 2015:1-7. 10.1155/2015/374178

37. Kim YJ, Park SO, Kim TH, Lee JH, Kim SH: The association of serum 25-hydroxyvitamin D and vertebral fractures in patients with type 2 diabetes. Endocr J. 2013, 179-184. 10.1507/endocri.EJ12-0269

38. Diaz IV, Barajas SE, Flores ZG, Rivera-Moscoso R, Osorio-Landa HK, Flores-Rebollar A: The impact of vitamin D levels on glycemic control and bone mineral density in postmenopausal women with type 2 diabetes. J Endocrinol Invest. 2015, 38:1365-1372. 10.1007/s40618-015-0394-4

39. Yaribeygi H, Maleki M, Sathyapalan T, Iranpanah H, Orafai HM, Jamialahmadi T, Sahebkar A: The molecular mechanisms by which vitamin D improve glucose homeostasis: a mechanistic review. Life Sci. 2020, 244:117305. 10.1016/j.lfs.2020.117305 